University of Nebraska - Lincoln

DigitalCommons@University of Nebraska - Lincoln

1970

\title{
Influence of Dietary Supplements of Vitamin D3 and Various Fats on Cholesterol and Fatty Acid Composition of the Blood and Body of Growing-Finishing Swine
}

\author{
M. H. Jurgens \\ lowa State University \\ E. R. Peo, Jr. \\ University of Nebraska-Lincoln \\ P. E. Vipperman, Jr. \\ University of Nebraska-Lincoln \\ R. W. Mandingo \\ University of Nebraska-Lincoln
}

Follow this and additional works at: https://digitalcommons.unl.edu/animalscifacpub

Part of the Animal Sciences Commons

Jurgens, M. H.; Peo, Jr., E. R.; Vipperman, Jr., P. E.; and Mandingo, R. W., "Influence of Dietary Supplements of Vitamin D3 and Various Fats on Cholesterol and Fatty Acid Composition of the Blood and Body of Growing-Finishing Swine" (1970). Faculty Papers and Publications in Animal Science. 634.

https://digitalcommons.unl.edu/animalscifacpub/634

This Article is brought to you for free and open access by the Animal Science Department at DigitalCommons@University of Nebraska - Lincoln. It has been accepted for inclusion in Faculty Papers and Publications in Animal Science by an authorized administrator of DigitalCommons@University of Nebraska - Lincoln. 


\title{
INFLUENCE OF DIETARY SUPPLEMENTS OF VITAMIN $\mathrm{D}_{3}$ AND VARIOUS FATS ON CHOLESTEROL AND FATTY ACID COMPOSITION OF THE BLOOD AND BODY OF GROWING-FINISHING SWINE ${ }^{1}$
}

\author{
M. H. Jurgens, ${ }^{2}$ E. R. Peo, Jr., P. E. Vipperman, JR. and R. W. Mandigo ${ }^{3}$ \\ Nebraska Agricultural Experiment Station, Lincoln
}

$\mathrm{P}$ REVIOUS work at this station suggested that vitamin $\mathbf{D}_{2}$, when fed with or without dietary cholesterol, depressed blood cholesterol levels of swine (Jurgens, Peo and Vipperman, 1967) and rats (Jurgens, Blunn and Peo, 1968). While not proven to be the cause, blood cholesterol levels have been used as one of the main criteria to estimate the development of atherosclerosis in man (Rabinowitz, Meyerson and Wohl, 1960; Swell, Law and Treadwell, 1962). Several investigators have reported that supplementation of unsaturated fats (Ahrens et al., 1957; Okey and Lyman, 1957; Avigan and Steinberg, 1958; Peifer, 1966) and especially linoleic acid (Jagannathan, 1962; Swell et al., 1962), into the diet will reduce blood cholesterol levels. Thus, the present work was undertaken to study the effects of dietary supplements of vitamin $\mathrm{D}_{3}$ with either a highly unsaturated fat (safflower oil) or a highly saturated fat (coconut oil) on the cholesterol content of blood and the cholesterol and fatty acid composition of certain tissues of growing-finishing swine.

\section{Experimental Procedure}

Thirty-six crossbred barrows and gilts averaging $65 \mathrm{~kg}$ were assigned at random to six experimental treatments. Six pigs were allotted to each treatment with equal distribution of sex. Housing and management of the pigs prior to and during the course of the experiment were essentially the same as described by Jurgens and Peo (1970).

Composition of the experimental diets and calculated analyses are shown in table 1 and were as follows: (A) control diet (corn-soybean meal); (B) control diet plus 1,100 IU/ $\mathrm{kg}$ vitamin $\mathrm{D}_{3}$; diets $\mathrm{C}$ and $\mathrm{D}$ and $\mathrm{E}$ and $\mathrm{F}$ (corn-SBM) containing $10 \%$ safflower and

1 Published with the approval of the Director as Paper No. 2644, Journal Series, Nebr. Agr. Exp. Sta.

2 Present address: Iowa State University, Ames.

3 Department of Animal Science. Acknowledgement is made to John Welch for assistance in development of certain of the laboratory procedures and to $P$. J. Cunningham and associates for care of the experimental animals. coconut oil, respectively. In addition, 1,100 $\mathrm{IU} / \mathrm{kg}$ of vitamin $\mathrm{D}_{3}$ were supplemented to diets $D$ and $F$. Since the diets differed in energy levels, all diets were formulated to contain equal quantities of other nutrients per kcal of metabolizable energy. The experiment was terminated after 56 days when the pigs reached an average body weight of 114 kilograms. Criteria of response included backfat thickness, area of the longissimus dorsi and its fat content, blood serum cholesterol and cholesterol and fatty acid contents of the liver, $l$. dorsi and inner and outer layers of backfat.

Approximately $10 \mathrm{ml}$ of blood were collected from each pig and total serum cholesterol was measured initially and at the termination of the experiment. B \& D vacutainer bleeding tubes ${ }^{4}$ with $3.8 \mathrm{~cm}, 20$ gauge needles were used to obtain blood from the brachial veins. The collected blood was allowed to coagulate, then it was centrifuged and the serum removed for chemical analysis.

The carcasses were allowed to cool for 24 hr after slaughter and the backfat thickness was determined from the average of three measurements taken at the first rib, last rib and last lumbar vertebra. The right loin from each carcass was divided between the 10th and 11 th rib and the area of the $l$. dorsi was determined by standard methods. The 11-12th rib section of the loin was removed, trimmed of any excess fat, ground and stored frozen until needed for cholesterol and fatty acid analyses. A sample of backfat (inner and outer layer) was also taken from over the 11-12th rib section and stored frozen.

The fat content of the $l$. dorsi was determined by standard methods as described by A.O.A.C. (1960). Total blood serum cholesterol was determined on duplicate samples by a colorimetric method described by Pearson, Stern and McGavack (1953). Cholesterol content of $l$. dorsi, backfat and liver was determined by modifying the method outlined

\footnotetext{
${ }^{1}$ Beckton-Dickinson, Rutherford, New Jersey.
} 
TABLE 1. COMPOSITION OF EXPERIMENTAL DIETS ${ }^{\text {a }}$

\begin{tabular}{lcr}
\hline & \multicolumn{2}{c}{ Basal diets } \\
\cline { 2 - 3 } Ingredient & A and B & C to F \\
\hline & $\%$ & $\%$ \\
Ground yellow corn & 83.10 & 66.10 \\
Soybean meal & 13.00 & 19.70 \\
Fat & 0.00 & 10.00 \\
Dicalcium phosphate $_{\text {Ground limestone }}$ & 2.00 & 2.40 \\
Salt (iodized) $_{\text {Trace mineral premix }}{ }^{\mathrm{c}}$ & 0.30 & 0.15 \\
Vitamin-antibiotic premix $^{\mathrm{d}}$ & 0.50 & 0.54 \\
- & 0.10 & 0.11 \\
\hline
\end{tabular}

a Calculated analyses

\begin{tabular}{cccc} 
Diet & Protein $\%$ & $\begin{array}{c}\text { Vitamin } \\
\text { IU } / \mathrm{kg}\end{array}$ & $\begin{array}{c}\text { Supplemental } \\
\text { fat, } \%\end{array}$ \\
\hline A & 14.0 & 0 & 0 \\
B & 14.0 & 1100 & 0 \\
C & 15.8 & 0 & 10 (safflower) \\
D & 15.8 & 1100 & 10 (safflower) \\
E & 15.8 & 0 & 10 (coconut) \\
F & 15.8 & 1100 & 10 (coconut) \\
\hline
\end{tabular}

${ }^{b}$ Diets in treatments $\mathrm{C}$ and $\mathrm{D}$ contain safflower oil and in treatments $\mathbf{E}$ and $\mathrm{F}$ contain coconut oil.

c Composition (\%): $\mathrm{Mn}, 10.0 ; \mathrm{Fe}, 10.0 ; \mathrm{Cu}, 1.0 ; \mathrm{Co}, 0.10$; I, $0.30 ; \mathrm{Zn}, 10.0 ;$ and $\mathrm{Ca}, 9.1$. Calcium Carbonate Company, Quincy, Illinois.

Quincy, lllinois. d Contributed the following amounts of vitamins and anti-
biotics per kilogram of diet. Diets $\mathrm{A}$ and $\mathrm{B}$ : vitamin $\mathrm{A}, 1,322$ $\mathrm{IU}$; riboflavin, $1.0 \mathrm{mg}$; niacin, $11.0 \mathrm{mg}$; calcium pantothenate $5.3 \mathrm{mg}$ : choline chloride, $33.0 \mathrm{mg}$; vitamin $\mathrm{B}_{12}, 11.0 \mathrm{mcg}$; and antibiotic, $23.0 \mathrm{mg}$. Diets $\mathrm{C}$ to $\mathrm{F}$ : vitamin A, 1,493 IU; riboflavin, $1.2 \mathrm{mg}$ : niacin, $12.4 \mathrm{mg}$; calcium pantothenate, $6.6 \mathrm{mg}$. choline chloride, $15.0 \mathrm{mg}$; vitamin $\mathrm{B}_{12}, 12.4 \mathrm{mcg}$; and antibiotic, $24.8 \mathrm{mg}$.

by Stromer, Goll and Roberts (1966) to the extent that a $2 \mathrm{~g}$ wet sample was extracted rather than a 4 g lyophilized sample.

Determinations were made for the percentage of the following identified methyl esters of fatty acids: myristic (14:0), palmitic (16:0), palmitoleic $(16: 1)$, stearic $(18: 0)$, oleic $(18: 1)$ and linoleic $(18: 2)$ by the methods outlined by Jurgens and Peo (1970).

Analyses of variances as outlined by Steel and Torrie (1960) were used for statistical appraisal of data.

\section{Results and Discussion}

The fat and fatty acid composition of the diets is given in table 2. The fat contents (ether extract) of the basal, safflower oil and coconut oil diets were $3.3,12.1$ and $12.1 \%$, respectively. Although the safflower and coconut oil diets were formulated to contain $10 \%$ supplemental fat, some of the fat may have been lost by seepage and absorption when the feed was stored.

The effects of vitamin $\mathrm{D}_{3}$ with a basal corn-soybean meal diet, basal plus safflower oil or basal plus coconut oil on blood and certain carcass traits are presented in table 3 . Car- casses of barrows had significantly $(\mathrm{P}<.05)$ more backfat thickness than gilts (5.2 vs. $4.8 \mathrm{~cm}$ ) which is consistent with previous findings of Bruner et al. (1958), Cox (1963) and Wagner et al. (1963). Backfat thickness was also significantly $(\mathrm{P}<.05)$ greater on carcasses of pigs fed diets with added fat $(5.2$ vs. $4.8 \mathrm{~cm}$ ). Similar results have been reported in studies with peanut oil and beef tallow (Barrick et $a l .$, 1953) and with stabilized lard (Kennington, Perry and Beeson, 1958).

Area of the $l$. dorsi and percent of fat therein were larger $(\mathrm{P}<.01)$ and smaller, respectively, in gilts compared to barrows (34.1 vs. 31.0 $\mathrm{cm}^{2}$ and $3.4 \mathrm{vs} .4 .0 \%$ ). The larger $l$. dorsi area in gilts is in agreement with work reported by Self, Bray and Reierson (1957), Bruner et al. (1958), Judge (1964) and Brooks (1967). Wagner et al. (1963) and Brooks (1967) also reported a lower percentage of $l$. dorsi intramuscular fat in gilts compared to barrows. The percent of $l$. dorsi fat in pigs fed safflower oil was significantly greater $(\mathrm{P}<.01)$ than of pigs fed coconut oil (4.6vs. $2.7 \%)$.

Final blood cholesterol levels were increased $(\mathrm{P}<.01)$ in pigs fed diets containing added fat with the largest increase in the pigs fed the highly saturated coconut oil. Barnes et al. (1959) reported similar results with adult swine fed either unsaturated fat (corn oil) or saturated fat (butter). Final blood cholesterol of pigs fed the basal diet increased $3.8 \%$ over initial levels while that of the pigs fed supplemental vitamin $\mathrm{D}_{3}$ declined by $4.1 \%$. Pigs fed supplemental safflower oil had initial to final blood cholesterol increases of

TABLE 2. FAT AND FATTY ACID CONTENT OF EXPERIMENTAL DIETS

\begin{tabular}{|c|c|c|c|}
\hline \multirow[b]{2}{*}{ Item } & \multicolumn{3}{|c|}{$\operatorname{Diet}^{a}$} \\
\hline & $\begin{array}{c}\text { A and B } \\
\text { Corn-SBM } \\
\text { basal }\end{array}$ & $\begin{array}{c}\text { C and D } \\
\text { Corn-SBM } \\
+10 \% \\
\text { safflower }\end{array}$ & $\begin{array}{c}\mathbf{E} \text { and } \mathbf{F} \\
\text { Corn-SBM } \\
+10 \% \\
\text { coconut }\end{array}$ \\
\hline $\begin{array}{l}\text { Fat, \% (ether } \\
\text { extract) }\end{array}$ & 3.3 & 12.1 & 12.1 \\
\hline Fatty acids $(\%)$ & & & \\
\hline $\begin{array}{l}\text { Myristic } \\
\text { Palmitic } \\
\text { Stearic } \\
\text { Total saturated } \\
\text { Palmitoleic } \\
\text { Oleic } \\
\text { Linoleic }\end{array}$ & $\begin{array}{r}1.0 \\
19.1 \\
2.8 \\
22.9 \\
1.6 \\
25.4 \\
50.1\end{array}$ & $\begin{array}{r}+{ }^{b} \\
10.7 \\
1.4 \\
12.1 \\
1.0 \\
13.5 \\
73.5\end{array}$ & $\begin{array}{r}35.8 \\
19.8 \\
3.5 \\
59.1 \\
2.6 \\
18.0 \\
20.4\end{array}$ \\
\hline
\end{tabular}

Average values for each fat type.

$b+=$ traces, but amount was too small to measure. 
TABLE 3. EFFECT OF DIETARY VITAMIN $D_{3}$ AND VARIOUS FATS ON BLOOD AND CERTAIN TRATTS

\begin{tabular}{|c|c|c|c|c|c|c|c|c|}
\hline \multirow[b]{4}{*}{ Item } & & & \multicolumn{6}{|c|}{ Treatment } \\
\hline & \multirow{2}{*}{\multicolumn{2}{|c|}{ Sex }} & \multirow{3}{*}{$\begin{array}{c}\text { A } \\
\text { C-S } \\
\text { Basal }\end{array}$} & \multirow{3}{*}{$\begin{array}{c}\mathrm{B} \\
\mathrm{C}-\mathrm{S} \\
\text { Basal } \\
+\mathrm{D}_{3}\end{array}$} & $\mathrm{C}$ & \multirow{3}{*}{$\begin{array}{c}\mathrm{D} \\
\mathrm{C}-\mathrm{S} \\
+\mathrm{safff} . \\
+\mathrm{D}_{3}\end{array}$} & \multirow{3}{*}{$\begin{array}{c}\mathrm{E} \\
\mathrm{C}-\mathrm{S} \\
+\mathrm{coc}\end{array}$} & \multirow{3}{*}{$\begin{array}{c}\mathrm{F} \\
\mathrm{C}-\mathrm{S} \\
+\mathrm{coc} . \\
+\mathrm{D}_{3}\end{array}$} \\
\hline & & & & & \multirow{2}{*}{$\begin{array}{c}\text { C-S } \\
\text { +-saff. }\end{array}$} & & & \\
\hline & Barrows & Gilts & & & & & & \\
\hline \multirow{5}{*}{$\begin{array}{l}\text { No. of pigs }{ }^{\mathrm{b}} \\
\text { Avg backfat, } \mathrm{cm}^{\mathrm{c}, \mathrm{a}} \\
\text { L. dorsi area, } \mathrm{cm}^{2 \mathrm{e}} \\
\text { L. dorsi fat, } \%^{\mathrm{f}} \\
\text { Initial blood chol., } \\
\quad \mathrm{mg} / 100 \mathrm{ml}\end{array}$} & 18 & 18 & 6 & 6 & 6 & 6 & 6 & 6 \\
\hline & 5.2 & 4.8 & 4.8 & 4.8 & 5.2 & 5.2 & 5.1 & 5.2 \\
\hline & 31.0 & 34.1 & 32.2 & 31.6 & 30.0 & 33.8 & 34.3 & 33.5 \\
\hline & 4.0 & 3.4 & 3.4 & 4.2 & 4.4 & 4.7 & 2.4 & 3.0 \\
\hline & 99.9 & 106.8 & 95.9 & 109.1 & 105.0 & 98.8 & 102.9 & 108.7 \\
\hline $\begin{array}{l}\text { Final blood chol., } \\
\mathrm{mg} / 100 \mathrm{ml}\end{array}$ & 123.6 & 128.9 & 99.5 & 104.6 & 123.1 & 134.4 & 148.9 & 147.2 \\
\hline \multirow{2}{*}{ Liver chol. mg/g } & & & & & & & & \\
\hline & 2.03 & 1.92 & 1.94 & 1.80 & 2.06 & 2.12 & 1.89 & 2.06 \\
\hline $\begin{array}{l}\text { L. dorsi chol. mg/g } \\
\text { wet tissue }\end{array}$ & 0.44 & 0.43 & 0.44 & 0.44 & 0.43 & 0.44 & 0.44 & 0.45 \\
\hline $\begin{array}{l}\text { Inner backfat chol., } \\
\text { mg/g wet tissue }\end{array}$ & 0.46 & 0.44 & 0.49 & 0.49 & 0.44 & 0.44 & 0.40 & 0.43 \\
\hline $\begin{array}{l}\text { Outer backfat chol,, } \\
\mathrm{mg} / \mathrm{g} \text { wet tissue }{ }^{\mathrm{a}, \mathrm{f}, \mathrm{i}}\end{array}$ & 0.47 & 0.47 & 0.48 & 0.51 & 0.44 & 0.49 & 0.42 & 0.46 \\
\hline \multicolumn{9}{|c|}{$\begin{array}{l}\text { a Corn-soybean meal basal diets. } \\
\text { b One pen of } 6 \text { pigs /treatment. } \\
\text { e Sex effect sig. } P<.05 \text { level. } \\
\text { d Difference between none and any fat sig. } P<.05 \text { level. } \\
\text { e Sex effect sig. } P<.01 \text { level. } \\
\text { r Effect of vitamin } D \text { s sig. P }<.05 \text { level. } \\
\text { g Difference between safflower and coconut sig. } P<.01 \text { level. } \\
\text { h Difference between none and any fat sig. } P<.01 \text { level. } \\
\text { I Sex x fat type interaction sig. } P<.05 \text { level. }\end{array}$} \\
\hline
\end{tabular}

17.2 and $36.0 \%$ without and with supplemental vitamin $\mathrm{D}_{3}$, respectively. The pigs receiving coconut oil diets had an initial to final blood cholesterol increases of 44.7 and $35.4 \%$ without and with vitamin $\mathbf{D}_{3}$. Thus, a possible hypocholesterolemic effect was observed when vitamin $D_{3}$ was supplemented to the basal and coconut oil diets. Although addition of vitamin $\mathrm{D}_{3}$ to the coconut oil diet did not result in a significant reduction in blood cholesterol content, the percentage of increase from initial to final levels was not as great in the vitamin $\mathrm{D}_{3}$ supplemented group. Addition of vitamin $D_{3}$ to the safflower oil diet further increased blood cholesterol levels.

The liver cholesterol of the pigs fed the added fat was significantly greater $(\mathrm{P}<.05)$ than the non-supplemented group (2.03 vs. $1.87 \mathrm{mg} / \mathrm{g}$ ). Studies with rats also indicate increases in liver cholesterol levels resulting from the addition of dietary fat (Grunbaum et al., 1957; Nath et al., 1959; Quackenbush and Pawlowski, 1960). The greatest concentration of liver cholesterol in the present study was from pigs fed the safflower oil diets. Similar results have been reported from studies with rats fed either corn oil (Avigan and Steinberg, 1958) or safflower oil (Alpert and Geller, 1968). Although not significant, the inclusion of dietary vitamin $\mathrm{D}_{3}$ with the fat supplemented diets resulted in higher liver cholesterol levels than occurred without added vitamin $\mathbf{D}_{3}(2.09$ vs. $1.97 \mathrm{mg} / \mathrm{g})$. The liver cholesterol of barrows was greater than that of gilts $(2.03$ vs. $1.92 \mathrm{mg} / \mathrm{g})$ but the sex effect was not significant.

The concentration of cholesterol in the $l$. dorsi was not significantly affected by dietary treatment. A sex $\mathrm{x}$ fat type interaction $(\mathrm{P}<.05)$ indicates a difference in response of the barrows and gilts to the dietary fat.

The addition of fat to the basal diet resulted in a significant reduction in cholesterol content of the inner $(\mathrm{P}<.01)$ and outer $(\mathrm{P}<.05)$ layers of backfat $(0.49$ vs. $0.43 \mathrm{mg} / \mathrm{g}$ and 0.59 vs. $0.45 \mathrm{mg} / \mathrm{g}$, respectively). The inclusion of vitamin $\mathrm{D}_{3}$ in each type of diet significantly $(\mathrm{P}<.05)$ increased cholesterol concentration of the outer backfat layer.

The fatty acid content of the liver, $l$. dorsi intramuscular fat and inner and outer layers of backfat is summarized in table 4. Three principal saturated and unsaturated fatty acids were determined with the sum of myristic, palmitic and stearic representing the total for the saturates and that of palmitoleic, oleic and linoleic the unsaturates. A survey of 
VITAMIN $D_{3}$ AND FATS FOR SWINE

TABLE 4. EFFECT OF DIETARY VITAMIN $D_{3}$ AND VARIOUS FATS ON FATTY ACID COMPOSITION OF LIVER, INTRAMUSCULAR FAT FROM $L$. DORSI AND

INNER AND OUTER LAYERS OF BACKFAT (\%)

\begin{tabular}{|c|c|c|c|c|c|c|c|c|}
\hline \multirow{4}{*}{$\begin{array}{l}\text { Fatty acid } \\
\text { composition }\end{array}$} & \multirow{3}{*}{\multicolumn{2}{|c|}{ Sex }} & \multicolumn{6}{|c|}{ Treatment } \\
\hline & & & \multirow{3}{*}{$\begin{array}{r}\text { A } \\
\text { C-S } \\
\text { Basal }\end{array}$} & \multirow{3}{*}{$\begin{array}{c}\text { B } \\
\text { C-S } \\
\text { Basal } \\
+D_{3}\end{array}$} & $\mathrm{C}$ & \multirow{3}{*}{$\begin{array}{c}\mathrm{D} \\
\mathrm{C}-\mathrm{S} \\
+\mathrm{saff} . \\
+\mathrm{D}_{3}\end{array}$} & $\mathrm{E}$ & \multirow{3}{*}{$\begin{array}{c}\mathbf{F} \\
\mathrm{C}-\mathrm{S} \\
+\mathrm{coc} . \\
+\mathrm{D}_{\mathbf{3}}\end{array}$} \\
\hline & & & & & \multirow{2}{*}{$\begin{array}{l}\text { C-S } \\
+ \text { saff. }\end{array}$} & & \multirow{2}{*}{$\begin{array}{l}\mathrm{C}-\mathrm{S} \\
+\mathrm{coc}\end{array}$} & \\
\hline & Barrows & Gilts & & & & & & \\
\hline \multicolumn{9}{|l|}{ Liver } \\
\hline $14: 0^{b}$ & 1.4 & 1.1 & 1.1 & 1.2 & 0.9 & 0.7 & 1.6 & 2.0 \\
\hline $16: 0^{b, c, d}$ & 20.7 & 21.7 & 24.1 & 22.4 & 19.5 & 16.8 & 23.5 & 20.9 \\
\hline $18: 0$ & 31.0 & 30.9 & 25.7 & 33.3 & 32.0 & 30.4 & 31.8 & 32.6 \\
\hline Total for sat. & 53.1 & 53.7 & 50.9 & 56.9 & 52.4 & 47.9 & 56.9 & 55.5 \\
\hline $16: 1$ & $+{ }^{e}$ & + & + & + & + & + & + & + \\
\hline $18: 1^{f}$ & 22.3 & 20.5 & 28.4 & 22.3 & 18.1 & 17.8 & 21.5 & 20.2 \\
\hline $18: 2^{\mathbf{b}, \mathbf{f}}$ & 24.6 & 25.7 & 20.7 & 20.8 & 29.4 & 34.3 & 21.6 & 24.3 \\
\hline \multicolumn{9}{|c|}{$\begin{array}{l}\text { Intramuscular fat } \\
\quad \text { of } l \text {. dorsi }\end{array}$} \\
\hline $14: 0^{b, d}$ & 2.4 & 2.5 & 2.0 & 2.4 & 2.2 & 1.8 & 3.2 & 3.4 \\
\hline $16: 0^{g}$ & 28.6 & 30.5 & 30.5 & 29.9 & 29.4 & 28.8 & 28.9 & 30.0 \\
\hline $18: 0^{\mathrm{h}}$ & 9.2 & 8.8 & 9.0 & 8.2 & 8.4 & 9.2 & 9.2 & 9.8 \\
\hline Total for sat. & 40.3 & 41.8 & 41.5 & 40.5 & 40.0 & 39.8 & 41.3 & 43.2 \\
\hline $16: 1^{h, j}$ & 5.4 & 5.6 & 6.3 & 5.6 & 5.0 & 4.7 & 5.2 & 6.3 \\
\hline $18: 1^{b, f, g}$ & 39.0 & 36.5 & 42.3 & 41.7 & 34.9 & 33.5 & 36.5 & 37.6 \\
\hline $18: 2^{b, f, k}$ & 15.2 & 16.2 & 9.9 & 12.1 & 20.1 & 22.0 & 17.1 & 12.9 \\
\hline \multicolumn{9}{|l|}{ Inne: backfat } \\
\hline $14: 0^{\mathrm{b}, \mathrm{f}}$ & 4.6 & 4.5 & 2.1 & 1.8 & 1.7 & 1.5 & 10.5 & 9.9 \\
\hline $16: 0^{13}$ & 26.6 & 26.4 & 26.7 & 27.2 & 22.1 & 21.1 & 30.0 & 31.5 \\
\hline $18: 0^{r}$ & 10.2 & 9.7 & 11.2 & 10.7 & 9.5 & 9.0 & 9.2 & 10.1 \\
\hline Total for sat." & 41.4 & 40.6 & 40.0 & 39.7 & 33.3 & 31.7 & 49.7 & 51.5 \\
\hline $16: 1^{b}$ & 4.0 & 4.1 & 4.1 & 4.2 & 3.0 & 2.4 & 6.0 & 4.8 \\
\hline $18: 1^{\mathbf{b}, \mathbf{f}}$ & 38.3 & 37.6 & 45.3 & 56.6 & 32.3 & 32.4 & 35.7 & 35.4 \\
\hline $18: 2^{\mathbf{b}, \mathbf{f}}$ & 16.2 & 17.7 & 10.6 & 9.6 & 31.4 & 33.5 & 9.6 & 8.2 \\
\hline \multicolumn{9}{|l|}{ Outer backfat } \\
\hline $14: 0^{b, f, I}$ & 4.2 & 4.2 & 2.4 & 2.0 & 2.1 & 1.6 & 8.9 & 8.2 \\
\hline $16: 0^{b}$ & 24.4 & 24.3 & 25.1 & 25.0 & 21.1 & 20.3 & 27.8 & 26.9 \\
\hline $18: 0^{\text {d }}$ & 7.8 & 7.8 & 9.3 & 8.0 & 7.0 & 7.2 & 7.5 & 8.0 \\
\hline Total for sat. ${ }^{b}$ & 36.4 & 36.4 & 36.8 & 35.0 & 30.2 & 29.1 & 44.2 & 43.1 \\
\hline $16: 1^{b, 1}$ & 5.3 & 4.9 & 5.3 & 4.7 & 3.9 & 3.3 & 7.4 & 6.2 \\
\hline $18: 1^{b, c, 1}$ & 41.3 & 40.9 & 45.0 & 48.6 & 36.1 & 36.4 & 39.4 & 40.7 \\
\hline $18: 2^{b, f}$ & 17.1 & 17.8 & 13.0 & 11.7 & 29.7 & 31.1 & 9.0 & 10.0 \\
\hline
\end{tabular}

a Corn-soybean meal basal diets.

$\mathrm{b}$ Difference between safflower and coconut oil sig. $\mathrm{P}<.01$ level.

c Effect of vitamin $\mathrm{D}_{3}$ sig. $\mathrm{P}<.05$ level.

a Difference between none and any fat sig. $P<.05$ level.

$\mathrm{e}+=$ traces, but amount too small to measure

$f$ Difference between none and any fat sig. $P<.01$ level.

$g$ Sex effect sig. $\mathrm{P}<.01$ level.

$n$ Sex $x$ vitamin $\mathrm{D}_{3}$ interaction sig. $\mathrm{P}<.05$ level.

i Sex effect sig. $\mathrm{P}<.05$ level.

$j$ Difference between safflower and coconut oil sig. $\mathrm{P}<.05$ level

k Vitamin $D_{3} \mathrm{x}$ fat type interaction sig. $\mathrm{P}<.01$ level.

1 Vitamin $\mathrm{D}_{3}$ effect sig. $\mathrm{P}<.05$ level

the literature indicates these fatty acids are the major straight-chained, even-numbered, monocarboxylic acids present in mammalian lipids (Hanahan, 1960). Palmitic acid was the principal saturated fatty acid found in muscle and backfat tissue; however, stearic acid was most abundant in the liver. Oleic acid was the primary unsaturate in all the tissues studied.

The myristic and palmitic acid contents were significantly $(\mathrm{P}<.01)$ lower in the livers of pigs fed safflower oil compared to the coconut oil group ( 0.8 vs. $1.8 \%$ and 18.1 vs. $22.2 \%$, respectively). The concentration of these fatty acids paralleled levels present in the diet. The inclusion of dietary vitamin $\mathrm{D}_{3}$ with each fat type reduced $(\mathrm{P}<.05)$ the palmitic acid content of the liver. To offset this effect, the pigs apparently attempted to maintain a fairly constant level of total satu- 
rated fatty acids by varying the deposition of stearic acid; i.e., stearic acid increased when palmitic acid decreased. Palmitoleic acid content of the liver was not present in large enough amounts to be accurately measured.

There was a definite treatment difference for oleic and linoleic acid contents of the liver. Livers from the pigs fed safflower oil contained significantly $(P<.01)$ more linoleic acid and significantly $(\mathrm{P}<.01)$ less oleic acid than livers from pigs fed the other diets. Feeding coconut oil resulted in the same levels of oleic and linoleic acids as those found in livers of pigs fed the basal diets (diets A and B).

The myristic acid content of the $l$. dorsi intramuscular fat was elevated in pigs fed coconut oil compared to those fed the basal or safflower oil diets. Dietary treatment did not affect the palmitic acid concentration of the $l$. dorsi intramuscular fat; however, tissue from gilts contained higher levels than tissue from barrows. When vitamin $D_{3}$ was added to each of the diets, stearic acid was reduced in $l$. dorsi intramuscular fat of barrows but increased in that of gilts. The increases of palmitic and stearic acid possibly explains the increased concentration $(\mathrm{P}<.05)$ of total saturated fatty acids in the $l$. dorsi intramuscular fat of gilts compared to barrows (41.8 vs. $40.4 \%$ ). The $l$. dorsi intramuscular fat from pigs fed coconut oil diets contained significantly more $(\mathrm{P}<.01)$ total saturated fatty acids than that from the safflower oil-fed group.

The palmitoleic, oleic and linoleic acid contents of $l$. dorsi intramuscular fat were all significantly affected by dietary treatment. Palmitoleic and oleic acid were lower and linoleic acid was higher with safflower oil as compared to coconut oil. A similar relationship was reported by Koch et ai. (1968) using safflower oil and tallow. The $l$. dorsi intramuscular fat of barrows from the experiment reported herein contained significantly $(\mathrm{P}<$ .01) more oleic acid than that of gilts.

The general pattern of fatty acid change due to dietary treatment was paralleled between the inner and outer backfat layers with the inner layer being more highly saturated. There was a significant $(P<.01)$ treatment difference for total saturated fatty acids of both backfat layers. Backfat from pigs fed safflower oil contained a lower level of total saturated fatty acids than that from either the control or coconut oil-fed group. Coconut oil feeding significantly $(\mathrm{P}<.01)$ increased the level of total saturated fatty acids compared to that of the safflower oil-fed group. The pattern for myristic, palmitic and stearic acid paralleled that for the total saturated fatty acids. The levels of myristic and palmitic acid were significantly higher in coconut compared to safflower oil-fed pigs. Stearic acid was significantly $(\mathrm{P}<.01)$ higher in the backfat of the control pigs compared to the fat-supplemented animals. The addition of vitamin $\mathrm{D}_{3}$ to any of the experimental diets resulted in a significant $(\mathrm{P}<.05)$ reduction of myristic acid of the outer backfat layer. Although not statistically significant, there was a trend toward reduced concentration of all the saturated fatty acids when vitamin $D_{3}$ was added to the diet.

There was a pronounced treatment difference for oleic acid and linoleic acid. Backfat from the pigs fed safflower oil contained significantly $(\mathrm{P}<.01)$ more linoleic acid and less oleic acid than that from the pigs fed the other diets. Feeding coconut oil produced levels of oleic and linoleic acids similar to those found in the pigs fed the corn-soybean meal basal diet. Similar results were observed for the changes of oleic and linoleic acid levels of the liver and $l$. dorsi intramuscular fat.

A comparison of the levels of linoleic acid in the feeds with the resulting depot fat indicates that dietary linoleic acid was preferentially deposited. This is consistent with the findings of Dahl and Perrson (1965) and Koch et al. (1968). Data suggests that the preferential deposition of linoleic acid reduced the level of total saturated fatty acids in the depots. A reduction in the oleic acid content may possibly have resulted from smaller quantities of oleic acid present in the safflower diet. The oleic acid content of the outer backfat layer was significantly increased with the addition of vitamin $D_{3}$ to each experimental diet. Conversely, supplementation with vitamin $\mathbf{D}_{3}$ caused a significant reduction in palmitoleic acid content of the outer backfat layer. The level of palmitoleic acid in safflower oil-fed pigs tended to be less than that for controls and was significantly less $(\mathrm{P}<.01)$ than that for the coconut oil-fed group.

The backfat of barrows contained more total saturated fatty acids than that from gilts. The levels of palmitic and stearic acids were greater for barrows while linoleic acid was greater in the backfat of gilts. These results agree with the findings reported by Koch $e t$ al. (1968). The outer backfat layer was more 
highly unsaturated than the inner layer in both barrows and gilts. This is consistent with the reports of Leat et al. (1964), Sink et al. (1964) and Koch et al. (1968).

In this study, final blood cholesterol levels were significantly elevated by the addition of $10 \%$ fat (safflower or coconut oil) to the basal diet with the greatest increase resulting from the highly saturated coconut oil. The observed increase suggests that intake of dietary fat per se may be closely associated with high blood cholesterol levels. Although there is general agreement that unsaturated oils may tend to reduce blood cholesterol levels while diets high in the saturated fats have the opposite effect, there is as yet no agreement upon fatty acids components presumed to be effective in increasing or decreasing the blood cholesterol level. Because of the difference in fat level of the present diets, the intake level of each fatty acid was much greater in the groups fed added fat compared to the basal diet. Thus, it appears that the greater intake of total saturated fatty acids by pigs fed the high-fat diets was responsible for the increased blood cholesterol levels. The coconut oil diet contained approximately five times the amount of total saturated fatty acids present in the safflower oil diet; therefore, blood cholesterol levels were further elevated in pigs fed coconut oil. Too, the higher levels of unsaturated fatty acids present in the safflower diet may have restricted the blood cholesterol levels from reaching those of pigs fed the coconut oil.

The data suggest that blood cholesterol is a function of the total saturated fatty acid and the polyunsaturated acid content of the dietary fat, the saturated fatty acids being more active in elevating the blood cholesterol than the polyunsaturated acids are in reducing it. The exact reason why saturated fatty acids may increase blood cholesterol is not clear. Nath and Brahmankar (1961) reported that rats receiving saturated fat excreted less bile acids than those receiving unsaturated fat. Gordon et al. (1957) suggested the hypocholesterolemic effect of unsaturates was associated with an increase in fecal output of bile acids. No attempt was made to verify these observations in the present experiment.

Liver cholesterol was greater in the safflower oil-fed pigs than those on the other treatments which is in agreement with several investigators supporting the concept that the blood cholesterol-lowering effect of polyunsaturated oil may be in part related to increased liver deposition or retention. Results of the present study suggest vitamin $\mathrm{D}$ and unsaturated fatty acids share a similar role as hypochölesterolemic agents but cannot act synergistically.

Although the effect of treatment and sex altered the blood and liver cholesterol concentrations, that of the $l$. dorsi was not markedly affected. Cholesterol content of the $l$. dorsi remained more stable than that of any of the other tissues examined.

\section{Summary}

A study was conducted to determine the effects of dietary supplements of vitamin $\mathbf{D}_{3}$ with a corn-SBM basal diet, basal $+10 \%$ safflower oil, or basal $+10 \%$ coconut oil on blood cholesterol and the cholesterol and fatty acid contents of certain tissues of growing-finishing swine.

Carcasses of barrows had greater backfat thickness and percentage of $l$. dorsi intramuscular fat but smaller $l$. dorsi area than carcasses from gilts. Supplemental dietary fat increased backfat thickness and percentage of $l$. dorsi fat in both barrows and gilts.

The blood and liver cholesterol levels of barrows were higher than those of gilts. Final blood cholesterol levels were reduced or at least arrested by the addition of vitamin $\mathrm{D}_{3}$ to the basal or coconut oil diets. However, when vitamin $D_{3}$ and safflower oil were fed in combination, blood cholesterol levels were increased.

Final blood cholesterol levels were significantly elevated by the addition of $10 \%$ fat (safflower or coconut oil) to the basal diet. The greatest increase resulted from the highly saturated coconut oil. The observations suggest that intake of dietary fats per se, accompanied by their higher levels of total saturated fatty acids, may be closely associated with high blood cholesterol levels.

The cholesterol content of the $l$. dorsi intramuscular fat and the inner and outer layers of backfat was quite similar with small variations due to dietary treatment. The fatty acid pattern of the three tissues was also similar but concentration varied with dietary treatment. The $l$. dorsi intramuscular fat of gilts was more highly saturated than that of barrows. However, the backfat of barrows contained higher levels of total saturated fatty acids than that of gilts. The inner backfat layer was more highly saturated than the outer layer in both barrows and gilts.

The evidence collected indicates that dietary intake of saturated fat (coconut oil) caused increased deposition of saturated fatty acids 
and elevated blood cholesterol levels while dietary intake of unsaturated fat (safflower oil) or vitamin $D_{3}$ caused increased deposition of unsaturated fatty acids, primarily linoleic acid, and reduced blood cholesterol levels. Although the fatty acid pattern of pork tissue was changed by manipulation of dietary fat, the cholesterol content remained quite stable.

\section{Literature Cited}

Aherns, E. H., W. Insull, R. Blomstrand, J. Hirsch, T. T. Tsaltas and M. L. Peterson. 1957. The influence of dietary fats on serum-lipid levels in man. Lancet 272:943.

Alpert, L. I. and S. A. Geller. 1968. Effect of safflower oil on hepatic deposition of cholesterol. Fed. Proc. 27:665.

A.O.A.C. 1960. Official Methods of Analysis (9th Ed.). Association of Official Agricultural Chemists. Washington, D. C

Avigan, J. and D. Steinberg. 1958. Effects of saturated and unsaturated fat on cholesterol metabolism in the rat. Proc. Soc. Exp. Biol. Med. 97:814.

Barnes, R. H., E. Kwong, G. Fiala, M. Rechcigl, R. N. Lutz and J. K. Loosli. 1959. Dietary fat and protein and serum cholesterol. I. Adult Swine. J. Nutr. 69:261.

Barrick, E. R., T. N. Blumer, W. L. Brown, F. H. Smith, S. B. Tove, H. L. Lucas and H. A. Stewart. 1953. The effects of feeding several kinds of fat on feed lot performance and carcass characteristics of swine. J. Anim. Sci. 12:899.

Brooks, C. C. 1967. Effect of sex, soybean oil, bagasse and molasses on carcass composition and composition of muscle and fat tissue in swine. J. Anim. Sci. 26:504.

Bruner, W. H., V. R. Cahill, W. L. Robison and R. F. Wilson. 1958, Performance of barrow and gilt littermate pairs at the Ohio Swine Evaluation Station. J. Anim. Sci. 17:875.

Cox, D. F. 1963. Breed and sex effects on the relationship between weight and fatness measured at a constant age in swine. J. Anim. Sci. 22:1091.

Dahl, O. and Kai-Ake Perrson. 1965. Properties of animal depot fat in relation to dietary fat. J. Sci. Food Agr. 16:452.

Gordon, H., B. Lewis, L. Eales and J. F. Brock. 1957. Effect of different dietary fats on the faecal and products of cholestrol metabolism. Nature 180:923.

Grunbaum, B. W., J. R. Geary, Jr., F. Grande, J. T. Anderson and D. Glick. 1957. Effect of dietary lipid on rat serum and liver cholesterol and tissue mast cells. Proc. Soc. Exp. Biol. Med. 94:613.

Hanahan, D. J. 1960. Lipid Chemistry. John Wiley and Sons, Inc., New York.

Jagannathan, S. N. 1962. Effect of feeding fat blends of hydrogenated groundnut (peanut) fat and cottonseed oil containing different levels of linoleic acid on serum cholesterol levels in monkeys (Macaca radiata) and liver cholesterol concentration in cholesterol-fed rats. J. Nutr. 77:317.

Judge, M. D. 1964. Comparisons of longissimus dorsi area of genetically similar barrows and gilts. T. Anim. Sci. 23:118.

Jurgens, M. H., E. R. Peo, Jr. and P. E. Vipperman, Jr. 1967. Effect of dietary cholesterol and vitamin $\mathrm{D}$ on growing-finishing swine. J. Anim. Sci. 26:1472. (Abstr.).
Jurgens, M. H., C. T. Blunn and E. R. Peo, Jr. 1968. Vitamin $\mathrm{D}_{2}$ and cholesteremia in the growing rat. J. Anim. Sci. 27:1153. (Abstr.).

Jurgens, M. H. and E. R. Peo, Jr. 1970. Influence of dietary supplements of cholesterol and vitamin $\mathrm{D}$ on certain components of the blood and body of growing-finishing swine. J. Anim. Sci. 30:894.

Kennington, M. H., T. W. Perry and W. M. Beeson. 1958. Effect of adding animal fat to swine rations. J. Anim. Sci. 17:1166. (Abstr.).

Koch, D. E., A. M. Pearson, W. T. Magee, J. A. Hoefer and B. S. Schweigert. 1968. Effect of diet on the fatty acid composition of pork fat. J. Anim. Sci. $27: 360$.

Leat, W. M. F., A. Culbertson, A. N. Howard and G. A. Gresham 1964. Studies on pigs reared on semi-synthetic diets containing no fat, beef tallow and maize oil: composition of carcass and fatty acid composition of various depot fats. J. Agr. Sci. $63: 311$.

Morrison, W. K. and L. M. Smith. 1964. Prepara tion of fatty acid methyl esters and dimethylacetals from lipids with boron fluoride-methanol. J. Lipid Res, 5:600.

Nath, M. C. and D. M. Brahmankar. 1961. Effect of vitamin $B_{12}$, unsaturated fat and hydrolyzed glucosecycloacetate on bile acid excretion in experimental hyperlipemia. Proc. Soc. Exp. Biol. Med. 108:337.

Nath, N., R. Wiener, A. E. Harper and C. A. Elvehjem. 1959. Diet and cholesteremia. I. Development of a diet for the study of nutritional factors affecting cholesteremia in the rat. J. Nutr. 67:289.

Okey, R. and M. M. Lyman. 1957. Dietary fat and cholesterol metabolism. I. Comparative effects of coconut and cottonseed oils at three levels of intake. J. Nutr. 61:523.

Pearson, S., S. Stern and T. H. McGavack. 1953. A rapid, accurate method for determination of total cholesterol in serum. Anal. Chem. 25:813.

Peifer, J. J. 1966. Hypocholesterolemic effects induced in the rat by specific types of fatty acid unsaturation. J. Nutr. 88:351.

Quackenbush, F. W. and M. D. Pawlowski. 1960. Effects of purified linoleic ester on cholesterol in the rat. J. Nutr. 72:196.

Rabinowitz, J. L., R. M. Meyerson and G. T. Wohl. 1960. Deposition of $C^{14}$ labelled cholesterol in the atheromatous aorta. Proc. Soc. Exp. Biol. Med. $105: 241$.

Self, H. L., R. W. Bray and R. J. Reierson. 1957. Lean cut yield and an evaluation of hams and loins of U.S.D.A. pork carcass grades. J. Anim. Sci. 16:642.

Sink, J. D., J. L. Watkins, J. H. Ziegler and R. C. Miller. 1964. Analysis of fat deposition in swine by gas-lipid chromatography. J. Anim. Sci. 23:121.

Steel, R. G, D. and J. H. Torrie. 1960. Principles and Procedures of Statistics. McGraw-Hill Book Co.. New York.

Stromer, M. H., D. E. Goll and J. H. Roberts. 1966. Cholesterol in subcutaneous and intramuscular lipid depots from bovine carcasses of different maturity and fatness. J. Anim. Sci. 25:1145.

Swell, L., M. D. Law and C. R. Treadwell. 1962. Tissue cholesterol ester and triglyceride fatty acid composition of rabbits fed cholesterol diets high and low in linoleic acid. J. Nutr. 76:429.

Wagner, G. R., A. J. Clark, V. W. Hays and V. C. Speer. 1963. Effect of protein-energy relationships on the performance and carcass quality of growing swine. J. Anim. Sci. 22:202. 